\title{
Empathy in the Phenomenological Tradition
}

Jardine, James Alexander; Szanto, Thomas

Published in:

The Routledge Handbook of Philosophy of Empathy

Publication date:

2017

Document version

Early version, also known as pre-print

Citation for published version (APA):

Jardine, J. A., \& Szanto, T. (2017). Empathy in the Phenomenological Tradition. In H. L. Maibom (Ed.), The Routledge Handbook of Philosophy of Empathy (pp. 86-97). Routledge. 
Forthcoming in: Heidi Maibom (Ed.). The Routledge Handbook of the Pbilosophy of Empathy. London \& New York: Routledge.

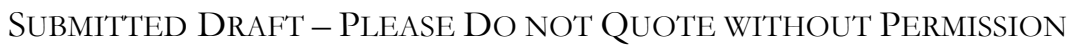

\title{
Empathy in the Phenomenological Tradition
}

\author{
James Jardine \& Thomas Szanto
}

\section{Introduction}

In the past few years, there has been a lively debate on whether and how phenomenology can contribute to social cognition research. In particular, it has been questioned whether first-personal, phenomenological evidence about intersubjective experience and interaction can support or disconfirm certain theories about social cognition. ${ }^{1}$ Most recently, it has been argued that while phenomenology "weakly constrains the study of social cognition" in the sense that "a theory of social cognition ought to be compatible with our phenomenological experience of social interactions," phenomenology would have no distinctive methodological contribution to debates about social cognition. For, in order to have such, phenomenological evidence would need to have three characteristics it allegedly lacks: it should be "novel" evidence, providing "information beyond what is widely acknowledged" and already presupposed, it should be "reliable" being "consistent, accurate, and unbiased", and "relevant", being able to "confirm or disconfirm some of the hypotheses debated" (Spaulding 2015, 1070-71). In this contribution, we will not directly address Spaulding's criticism, although it should

\footnotetext{
${ }^{1}$ See positively, arguing for phenomenology's contribution, e.g., Ratcliffe 2007; Fuchs \& De Jaegher 2009; Zahavi 2011, 2014; Gallagher 2012; Jensen \& Moran 2012; Krueger 2012; Overgaard 2012, and contra Currie 2008; Herschbach 2008; Jacob 2011; Spaulding 2010, 2015.
} 
be noted that phenomenologists would reject Spaulding's (not uncommon) understanding of phenomenological research as limited to first-personal introspective reports. ${ }^{2}$ Rather, our aim will be to present aspects of the rich and detailed discussion of empathy found in the phenomenological tradition, such that the reader can assess for him or herself whether the arguments and claims found there ought to be dismissed outright as scientifically and philosophically irrelevant, or whether they might rather contain important and subtle insights of contemporary relevance. ${ }^{3}$

Our approach in the following will be as follows. First, we will examine the account of empathy offered by the two phenomenologists whose writings on the topic we take to be the richest and clearest, Husserl and Stein, explicating their arguments for the claims that (i) empathy is a sui generis mode of intentional experience, (ii) the basic form of empathy can nevertheless be characterised as perception-like, and (iii) that a higher-order form of empathy is more an imagination-like way of understanding other persons from their own personal perspective. Moving beyond Husserl and Stein, we will then consider different types of empathic accomplishment that are more richly socially or collectively mediated, namely mutual, interactive, shared, and collective empathy, as well as considering the import of social roles and typification.

\section{Empathy as a Distinctive Form of Intentional Experience}

The English term 'empathy' only dates back to the beginning of the 20th Century, when it was first coined by Titchner (1909) to translate the concept of Einfüblung as employed by the German philosopher and psychologist Lipps. While the term first originated in 19th Century German aesthetics to designate an ability to 'feel oneself into' (Ein-füblen) works of art (Vischer 1873; cf. Mallgrave \& Ikonomou 1994), the now ubiquitous association of empathy with interpersonal relations can be largely traced back to Lipps' work. Importantly for our purposes, Lipps was both a source of inspiration and a target of opposition for the phenomenologists, and outlining the basic features of his account can thus be of aid in clarifying their own position.a

Lipps argued that there are three distinct regions of knowledge, namely, knowledge of things, self-knowledge, and knowledge of other selves. While the

\footnotetext{
2 Obviously, we cannot in any detail elaborate on the distinctiveness of the phenomenological method, here, for this, see Sokolowski 2000; Gallagher \& Zahavi 2012; Cerbone 2012.

${ }^{3}$ Due to our sole focus here on those phenomenologists who focus explicitly on the topic of empathy, we will not discuss the important work of phenomenologists (such as Heidegger, Sartre, and Levinas) on the broader but closely related issue of intersubjectivity cf. Zahavi 2001; Overgaard 2007; Theunissen 1966.
} 
first region has as its source sensuous perception and the second inner perception, our knowledge of other selves is rooted in empathy, which should accordingly be understood as a basic concept for both psychology and sociology (1909: 222; 1907: 713). Consequently, for Lipps, empathy is "the name for an original and irreducible, yet simultaneously wondrous, state of affairs," namely the ability to "co-grasp" foreign mental states "in and with" the perceptual apprehension of foreign bodies. Lipps' claim that empathy is an irreducible source of knowledge of other minds partially stems from his belief that, rather than being rooted in analogical inference, our basic grasp of other minds is a more "immediate" accomplishment. As he hastens to add, however, this should not lead us to believe that we can "see" or "know immediately" the other's anger itself, since the latter is something non-perceivable which can only be directly known by the person who feels it. Rather, our awareness of another person's affective state "in" her bodily expressions must be attributed, not to a direct experience of that state, but to what he calls the "instinct of empathy," which itself has two components, the "tendency of expression," and the "instinct of imitation." (1907: 713-4) Lipps' proposal, briefly, is that when perceptually faced with another's body as physically contorted in a certain way, the empathiser feels an instinctive tendency to imitate the other's bodily contortion. If the bodily contortion the empathiser is inclined to imitate coincides with a contortion she has previously performed in instinctively expressing an emotion, then her tendency to imitate in its turn reproduces an experience she has earlier had of this emotion. This recollected affect is then "represented" or "thought into" (vorgestellt, hineingedacht) the other's gesture as something which belongs to and is intimated in it (1907: 718-9; cf. 1909: 228). Furthermore, Lipps claims that empathy is not limited to the rather weak and preliminary ability to project one's own past emotional states into other people's bodily gestures; rather, in a second step, the empathising subject is instinctively moved to express and feel the otherwise merely recollected emotion in the present. Consequently, unless the natural course of empathising is interrupted by internal or external circumstances, empathy instinctively develops into a state of sympathy or emotional sharing (Sympathie, Mitfüblen), in which the empathising subject not only represents a mental state as belonging to the other's gesture, but actually feels and lives through the relevant emotion 'with' the other (1907: 71920).

Now, Lipps' core claim that empathy is a unique, irreducible, and immediate (i.e., non-inferential) experiential accomplishment and a basic source for knowledge of other minds was taken over and arguably radicalised by the phenomenologists. Thus, in her 1917 doctoral dissertation Zum Problem der Einfühlung, which Husserl supervised, Stein affirms that empathy is "a kind of experiential act sui generis," defining it as "the experience of foreign consciousness in general," or "the experience of foreign subjects and their lived experience" (1917: 20, 5 [11, 1, 
translation modified]). However, not only did Husserl and Stein criticise almost every detail of Lipps' account of empathy, ${ }^{4}$ they also offered a starkly different construal of this basic experiential and epistemic directedness towards others. One of the most important features of this controversy was the phenomenologists' insistence that the immediacy and distinctiveness of empathy was not only a matter of its non-inferential character, but also of its irreducibility to a Lippsian process which combines elements of body-perception, self-experience, and ultimately projection. This latter claim has two key components, which we will now explain.

(A) As Stein points out, the explanatory value of Lipps' account is questionable, in that somebody who perceived a physical entity whose movements evoked a recollection of her own prior expressive gestures would not thereby "arrive at the phenomenon of foreign lived experience, but at a lived experience of her own awoken by the seen foreign gestures" (1917: 36 [23, translation modified]). That is, one must first have some understanding of what the other is going through in order to recognise a similarity between one's own experiences and those of the other, and it is therefore logically muddled to suggest that any understanding of other minds could be fundamentally based upon the reproduction of a past experience of our own that putatively approximates the other's current mental state. Indeed, such an explanation seems better equipped to account for emotional contagion or motor mimicry than for an epistemic grasp of other minds (1917: 36-7 [23-4]). An arguably more fundamental worry Stein expresses about Lipps' view is that in modelling our basic empathetic grasp of other minds on the (projection of) self-experience, one overlooks the phenomenological fact that the givenness of others' mental lives is entirely different from the givenness of one's own mental life, having its own distinctive structure which phenomenological reflection can tease apart (1917: 24, 28 [14, 17]). To come face to face with another person's sadness is, after all, quite different from feeling sad oneself or remembering a sadness one felt earlier (1917: 20 [11]). And if, upon encountering another's sadness, one finds oneself sharing the other sadness or sympathising with it, then this shared or sympathised sadness is not the basic empathic access one has to the other's sadness but something more complex built upon and presupposing it (1917: 24-5, 28-9 [14, 17-18]; cf. section IV.). In short, empathy and self-awareness (in its various forms) do not only target a different object; as intentional experiences they also differ fundamentally in type and composition.

\footnotetext{
${ }^{4}$ See: Husserl (1905-1920: 38-41, 70-6, 187-8); Stein (1917: 21-30, 35-7, 93-101 [11-8, 22-4, 75-82]). Without being able to discuss the issue here, we find compelling Zahavi's detailed argument to the effect that the phenomenological criticisms of Lipps also pose a challenge to certain contemporary accounts of social cognition and empathy, and that the phenomenological account of empathy is consequently of contemporary relevance (2014: 95-194).
} 
(B) Furthermore, both Husserl and Stein attack Lipps' underlying presupposition that all that can be directly experienced of another person are the merely physical features of her body, arguing that such a postulated gap between foreign mindedness and the directly given is completely at odds with our lived acquaintance with others. As Husserl puts it, a basic form of empathy is rather "an immediate experience of others," in that our direct perception of another person is not merely instinctively accompanied by, but rather includes a certain "experience [of] the other's lived experiences," this being "accomplished as one with the originary experience of the [other's] body." (1912-1917: 375, 198 [385, 208]; cf. Stein 1917: $14-15,19,31,75,79[6-7,10,61])$. As will become clear in the next section, rather than beginning with the presupposition that other minds are (invisible) entities accessible only through the projection of one's own mental states into otherwise inanimate bodies (Lipps), the phenomenological account of empathy beings by attempting to systematically articulate the sense and manner in which others are directly visible as minded persons.

For phenomenologists, then, empathy is both our basic mode of access to other minded beings, and an irreducible form of intentional experience with a unique structure. As we shall see in the next two sections, this unique mode of intentionality is nevertheless multi-layered, incorporating different modes of accomplishment. Moreover, while the claim that empathy has sui generis intentional structure stipulates that empathic acts are not composed of or identical to other intentional acts, this does not prevent it from exhibiting some of the characteristic features of other modes of intentionality. While the most primitive form of empathy can be described as a perception-like experience, a more active form of empathy is more akin to imagination.

\section{Perception-like Empathy}

One of the more intriguing traits of phenomenological accounts of empathy is the frequent claim that a basic form of empathy shares important characteristics with the perceptual experience of non-minded entities, without nevertheless being strictly identical to the latter. Consider a perceptual episode which might be appropriately expressed by the following description:

(1) "On turning the street corner, I saw a blue car heading straight towards me."

(1) expresses a certain kind of perceptual episode, and by reflecting upon it one may identify certain general features of perceptual experience, of which we will emphasise just three. (i) In perceiving an object, such as 'a blue car', or state of affairs, such as 'a blue car moving towards me', what we are directly and immedi- 
ately acquainted with is just the perceived object or state of affairs itself. In such cases, we take the object which appears to us to be the spatiotemporal object that is really there before us. This differs markedly from the way we experience an object in, say, imagination: in imagining 'a blue car moving towards me,' we do not typically take the imaginary object to be identical with an actual clunky entity heading in our direction. We can call this feature of perception its directness. (ii) A further general feature of perceptual experience is its epistemic role, namely that it can provide a prima facie justificatory basis for our (perceptual) judgements. Compare a person who thinks she was almost run over this morning, and does so because she earlier had a perceptual experience as of a car speeding towards her, with a person who holds the same belief but without having had any such experience. The former person surely has a justification for her belief than the latter lacks, even if her belief may ultimately be false. Call this the justificatory import of perception. (iii) A final feature of perception is what we will call its perspectival character. The perceptual experience expressed in (1) is an experience of a spatiotemporal object in motion, but it is one in which the moving object appears under a certain aspect or perspective, or more accurately, an aspectual series that unfolds as the blue car moves closer to the perceiver. Throughout this series, the perceiver does not experience each new aspect as a new object, but rather precisely sees the car as appearing under ever-new aspects, in that with each aspectual shift certain visible features of an identical object come (more clearly) into view, while others cease to be visible. In short, even in a momentary perceptual appearance one can distinguish phenomenologically between the presence of the object and that of its visible aspect, where the former is irreducible to, and only partially revealed by, the latter. $^{5}$

We can now consider to what extent empathic experience might embody these general features. Consider an experience expressed by the following description:

(2) "On turning the street corner, I saw someone glare at me angrily."

There is something inadequate in the suggestion that, were one to turn a corner and face such a person, what one would be experientially acquainted with is simply an inanimate entity. One might conclude from this that an empathetic grasp of the other's angry glare must then be rooted in an additional capacity which projects mental states into the directly given. However, it would also be phenomenologically inaccurate to claim that what appears directly in (2) is essentially the same as in (1), and that the subject turning the corner only thinks that someone is glar-

${ }^{5}$ One finds detailed and original discussions of perception in the phenomenological literature, which our brief summary here can only roughly intimate. See, in particular: Husserl (1907), Merleau-Ponty (1945), and Hopp (2011). 
ing at her angrily because the (wholly physical) entity she perceives is of such a kind as to set in motion a process of inference or simulation. Rather, a more accurate description of this experience would simply claim that what directly appears is just a person staring angrily, and that this is so irrespective of any process of imagining or thinking the subject may perform. In experiential episodes like this, what is immediately there before us experientially is surely not merely a material body, but a person, one whose facial expression displays an emotion (cf. Husserl 1912-1917: 240 [252]). It therefore seems that a compelling description accords to this experience perceptual feature (i), in that here the intentional object of our experience (namely the person glaring at us angrily) directly appears to us, is visibly there. This claim gains further weight when we note that such cases also exhibit feature (ii). The person undergoing experience (2) would surely gain a prima facie justification to believe that 'a person is glaring at me angrily,' not that 'an 'angry-looking' lump of flesh stands before me'-indeed, were she to believe the latter and claim to be perceptually justified in so doing, we might suspect her of suffering a pathology (or perhaps of being a particularly obstinate philosopher). It seems plausible, then, to claim that it is not only beliefs about the others' body, but also at least some which concern the other person as a whole (notably, a belief that she is currently angry), that gain a perceptual-like warrant in such cases. Finally, an encounter with another's angry glare exhibits feature (iii), in that we can distinguish between the object directly given and the aspect through which it perspectivally appears. While what we see is a person glaring at us angrily, the angrily glaring person is always given under a certain aspect; after all, in any moment of the perceptual episode only certain features of the others' body are directly visible.

One might think, however, that this last point actually counts against the claim that a basic form of empathy shares the directness characteristic of perception. If it is conceded that only certain features of the other's body can ever be directly visible, then it may seem to follow that a grasp of the other as a minded being could never be accomplished by any direct experience of her alone. The phenomenological account of empathy avoids this objection by insisting that, at least when it comes to the way others directly appear to us, the relationship between body and mind is not understood as a causal link between two separate entities, but as an expressive relation. We do not merely perceive the other person's directly visible countenances and gestures as meaningless physical events. Rather, to have such expressive movements directly in view just is to grasp their sense, that is, to see something of the other's emotive and practical condition:

Empathy into persons is nothing else then precisely that apprehension which understands the sense, i.e., which grasps the body in its sense and in the unity of the sense it has to bear. To perform an act of empathy means to grasp mind as an object, to see a human being, to see a crowd of people, etc. Here we do not have an 
apprehension of the body as bearer of something psychic in the sense that body is posited (experienced) as a physical object and then something else is added on to it, as if it was apprehended just as something in relation to, or conjunction with, something else $[\ldots]$ the body appears, but what we perform are the acts of comprehension, and what we grasp are the persons and the personal conditions "expressed" in the appearing content of the body. (Husserl 1912-1917: 244 [256, translation modified]; cf. 234-6, 240, 347 [246-7, 252, 358])

For the most part, we experience the other's bodily gestures and movements as intrinsically embodying mindedness, as movements lived through by someone; we see them as movements which the other purposively achieves or involuntarily suffers, which bring her perceptual world into ever-new orientations, or as the manifestations of her affects (Stein 1917: 79, 85, 93-103 [61-2, 67-8, 75-84]; Husserl 1912-1917: 322-3, 391 [335, 400]; Scheler 1926a: 254 [260]). Similarly, we see the other's limbs and skin as loci for fields of sensation, such that when an object comes into contact with the others' body we immediately grasp this contact as tactually lived, and sometimes as painful or pleasurable (Stein 1917: 75, 78 [57-8, 61]). To quote again Husserl, the "body is not only in general a thing but it is indeed expression of the mind and is at once organ of the mind." (1912-1917: 96 [102]). The conclusion that other people's mental states are inherently invisible only follows from the (valid) observation that their bodily features alone are directly visible if we picture the body as a meaningless physical entity. But once we appreciate that foreign bodies are directly visible as fields of expression, such reasoning loses much of its force.

It was emphasised earlier that both perceptual experience of nonexpressive objects and perception-like empathy have a perspectival character. Another way of putting this point is that in the very act of seeing a thing or a person we grasp the seen object as having more to it than what immediately meets the eye. To return to our earlier example, when facing a car heading towards us we do not merely see a free-floating bonnet; rather, we perceptually take the object to be a car, and as such we 'co-perceive' or 'co-intend' it as having other, currently non-visible features (a rear, an underside, a roof, etc.), these features being 'copresent' in our perception in that they contribute to the overall sense the seen object has for us (1918-1926: 3-7 [39-43]). When it comes to perception-like empathy, on the other hand, the other's body is not only seen as having materially more to it than what meets the eye, it is also seen as an expressive body that displays elements of the other's experiential life. Consequently, in seeing the other person we are not only acquainted with her body in its materiality through the structures of direct visibility and co-perception; in understanding the expressivity of her body, Husserl claims, we also achieve a certain 'envisaging' (Vergegenwärtigung) of the other's experiential life, which is 'made present' to us in a certain way. It is crucial not to misunderstand this claim. On the one hand, Husserl is not 
suddenly conceding that our basic empathic contact with others is dependent upon imaginative capacities; rather, he consistently emphasises that the envisaging he has in mind is simply a moment in our perception of the other as an expressive, embodied whole, a moment which has essentially the same role as that played by co-perception in the seeing of non-expressive objects (1912-1916: 198, 162-6 [208, 170-5]; cf. 1931: 150-1 [122-3], Stein 1917: 14-5, 19, 31, 75, 79 [6-7, $10,61])$. The envisaging in question is, therefore, more of an ambiguous sense that the other is undergoing an experience of a certain type, namely that one which is seen as alive before me 'in' the others' facial expressions and bodily movements. On the other hand, Husserl should not be understood as claiming that, while the others' physical features are directly presented, her mental features are only co-presented or envisaged. ${ }^{6}$ Such a claim cannot be correct, because as Husserl points out, much of what we directly encounter in other persons doesn't fall onto only one side of the mind-body distinction, being rather immediately embodied and experiential. Indeed, there is a sense in which every movement of the other's body is directly visible as, as it were, "full of soul"; consider how we see a person's "standing and sitting," or her "way of walking, dancing, and speaking” (1912-1916: 240 [252]; cf. Merleau-Ponty 1945: 225, 414 [214, 415]). The phenomenological claim that a moment of envisaging functions in perception-like empathy, then, simply affirms that our direct experience of persons as expressive unities necessarily involves a certain inarticulate awareness that the other's embodied enactments have an experiential dimension, that they are not only directly evident to the empathising subject but also lived through and accomplished by the other.

\section{Imagination-like Empathy and Interpersonal Understanding}

We emphasised at the beginning of this chapter that, by empathy, the phenomenologists mean our experience of other subjects and their lived experience, and they claim that such experience encompasses a sui generis class of intentional acts. As should now be clear, this bold claim is partially motivated by the observation that our encounters with others involve a certain kind of perception-like experience, possessing the directness, justificatory import, and perspectival character of our perceptual experience of inanimate objects, but differing from the latter in it that involves a direct encounter with another person who is recognised as having an experiential life of their own. It would, however, obviously be a mistake to think that our (empathetic) experience and understanding of the personal lives of

\footnotetext{
${ }^{6}$ This reading of the role of co-presence in empathy forms the basis of Smith's recent Husserl-inspired account of other-perception (2010: 739-41), though his particular reading has, we think, been persuasively criticised by Overgaard (2013).
} 
others is limited to our immediate quasi-perceptual contact with them. As Stein notes, when the other's sadness faces us as directly given in her facial expressions, we frequently "feel ourselves led by it" (1917: 31 [19]), in that the theme of our empathic interest becomes not only that the other is sad, but what she is sad about and why this state of affairs elicits sadness in her. In such cases, the other's experiential life "is no longer an object in the proper sense. Rather, it has pulled me into it, and I am no longer turned to the experience but to its object, I am in the position of its subject." Here, we are not merely directed towards the other in her embodied presence, but we enact a more active envisaging of the other's worlddirected experiential life, bringing it to mind 'as if we were its subject, in a manner more similar to memory, expectation, or imagination than perception. Importantly, Stein emphasises that this modality of empathy, which she characterises as a form of self-displacement or re-accomplishment (Hineinversetzen, Mitvollzug, Nachvolling), is derivative to and explicates the more basic modality discussed above (1917: 18-20, 32-3, 39, 51 [10-12, 20, 25, 34]). Moreover, just as the latter is not strictly identical to our perceptual experience of inanimate objects, this active envisaging or re-accomplishment should be distinguished from imagination, in that it targets a different domain of experiences (namely, those of the other, not an imaginary modification of oneself), and has a different type of epistemic import and motivation (1917: 19-20 [10-1]). ${ }^{7}$ Here too, then, empathy retains its irreducible and unique character.

In a similar vein, Husserl notes that the extent to which we take ourselves to have a sufficient understanding of another persons' actions or emotions is largely a matter of our practical interests. In our daily encounters with others, we often remain satisfied with "an intuitive presentation of a concrete minded being and mental life," that is, a direct and quasi-perceptual experience in which the other person is empathetically grasped merely in accordance with "the general types of human existence" (1915-1917: 580, 578; cf. Taipale 2016). Namely, in the bustle of everyday life, we often lack the interest to go beyond our initial grasp of the other as a token of the universal type, 'someone,' or as someone exhibiting a type of comportment (as someone walking briskly, smiling happily, or lost in thought) or embodying a certain socio-cultural type or role (an issue we shall return to below). However, if we are so interested, it is also possible for us to aim at a deeper empathetic understanding of the others' comportment, to seek to uncover the person's operative motives, values, and goals (1915-1917: 732-3). Hus-

${ }^{7}$ One can find a variety of interpretations of Stein's account of this level or modality of empathy in the secondary literature. See Zahavi (2014: 137f.), Jardine (2014), Shum (2012: 18595) and Dullstein (2013: 343-46). Jardine (forthcoming) discusses the differences and similarities between Stein's distinction between empathic perception and empathic envisioning (there labelled 'presentification' or 're-accomplishment') and Stueber's distinction between basic and re-enactive empathy, arguing that Stein's more fine-grained account is able to account for a greater diversity of empathic situations. 
serl claims that this ability is closely connected to our knowledge of the person's individual character. On the one hand, a deep understanding of the other's actions, emotions, and beliefs benefits from our having some knowledge of the person's individual character, and on the other hand, such an understanding is exactly a way of acquiring and increasing such knowledge (1915-1917: 734-5). Consequently, our ability to deeply understand the motivational context of another's actions is best seen as embedded within ongoing personal relationships, in which our epistemic familiarity with the other person's character has gradually developed through repeated empathic perception and, perhaps, communicative engagement (1912-1916: 274-275, 162 [286-287, 170]). However, when we know a person's character well, we are sometimes able to gain a rich understanding of both the 'what' and the 'why' of their actions by actively envisaging and 'reliving" the other's own agential perspective. This involves quasi-imaginatively representing the situation 'as if I were the other, taking into account the other's enduring values, habits, beliefs, and goals, and thereby understanding how the other's situation would lead the other to act. As Husserl emphasises, this is quite different from simply imagining how $I$ would act in the other's situation, in that I may be able to accomplish such an understanding even if I would respond to the other's situation in a wholly different way, and it is for this reason that such an active envisaging of the others' personal situation is a form of empathy, and not merely a form of imagination (1915-1917: 759, 755-756; cf. Goldie 2000: 178, 194-205; Coplan 2011).

\section{From Social Roles and Typification to 'Empathic Interaction', and 'Collective Empathy'}

In order to gain a multi-dimensional account of empathic encounters phenomenologists have emphasized that we have to move beyond the sole focus on bodily expressivity, and understand the role played by the broader social contexts into which the others are embedded. However, it is important to note that this is not meant to imply that there would be any conflict or rift between an allegedly purely personal and the broader social context of empathic understanding, quite the contrary, the two are constitutively intermeshed. Now, concerning this broader social context, two domains, in particular, have been at centre stage in recent social philosophy, both in the analytic and in the phenomenological tradition: on the one hand, the nature of social cognition and empathy; on the other hand, the possibility and nature of collective intentionality, group agency (Ludwig \& Jankowic 2016), and shared emotions (von Scheve \& Salmela 2014). Indeed, it is safe to say that phenomenology was the first intellectual tradition that has not only thoroughly investigated both these issues, but, moreover, even if not quite explicit- 
ly, their complex interrelation (Walther 1922; Stein 1922; Scheler 1926a, 1926b; cf. Chelstrom 2013; Szanto \& Moran 2015 and 2016; Szanto 2015, 2016). There are three crucial questions to be raised here: (i) Is empathy necessary for engaging in collective intentionality or agency, and if yes what type or form of empathy (mutual, dyadic, face-to-face, etc.)? (ii) According to a dominant view in current social cognition research, empathy must be distinguished from purely cognitive perspective-taking, or mindreading. Empathy, then, is characterized as being "caused by sharing the emotions of another person," or as the "simulation of the feelings of others" (Hein \& Singer 2008). In a similar vein, it has been argued that empathy is an affective state and requires "interpersonal similarity" between empathizer and target (Jacob 2011; De Vignemont \& Jacob 2012). As we have seen, however, the phenomenological account of empathy rejects this assumption. Phenomenologists claim that empathy is neither an affective state (but rather, as we have argued above, a sui generis intentional experience), nor does empathiser and target necessarily share any mental or affective states. But if empathy, for phenomenologists, does not involve intentional, emotional, or other forms of sharing, what is the relation between empathy and sharing? (iii.) Finally, are there non-dyadic or even collective forms of empathy? Here, we will only touch upon the first two issues (see however Zahavi 2014, 2015), and mainly focus on the latter question.

Generally, one may distinguish a number of related but distinct issues regarding empathy in broader social and collective contexts. First, there is the issue regarding the direction of empathic acts and, correspondingly, the respective (subject and object) relata of the empathic relation. For instance, in terms of the empathiser-target relation, we may want to know whether we have an individual-toindividual, an individual-to-pairs-of-individuals, an individual-to-group, a groupto-individual, or a group-to-group relation. Another issue concerns the kind of reciprocity or interaction between empathiser and target, may these be individuals or, potentially, groups.

Though most classical and early phenomenologists account or, at least, allow for a broad variety of empathiser-target-relations, in the following we will restrict our discussion to what we take to be the most important forms, notably to social typification, mutual or interactive empathy and finally shared or collective forms of empathy.

(1) First consider the issue of social typification in empathy, explored in detail in the phenomenological sociology of Schütz. Schütz has convincingly argued that in all forms and in all actual cases of interpersonal encounter, you will have a more or less explicit and more or less specific or fine-grained typification of the other(s) at play. Moreover, this process has no clear-cut boundaries, such that there will usually be an intermeshing or gradual transition from a more or less concrete, personal other in direct face-to-face encounters to a more or less 'anon- 
ymous' representative or proxy of a general or social type. Such typification for Schütz involves the recognition and grasping of an "objective web of meanings" (objektiver Sinnzusammenhang), practices, or social facts in which subjects are always and already embedded. For instance, when greeting the postman who just handed you a letter, you directly perceive both the nice smiling young man, as well as the anonymous one whom you were eagerly awaiting this morning, and maybe even the surprisingly friendly representative of the state-owned service that has recently been criticised for their bad-tempered, poorly paid employees. Importantly, Schütz stresses that social typification is fully compatible with the equally radical view that in a direct face-to-face encounter with another, I not only have a prereflective and direct epistemic access to the other's mind, but in a sense an even more direct access than I do to my own mind, which is always only given thematically in reflexive acts (Schütz 1932: 227-90; Schutz \& Luckmann 1975: 98-139; cf. Zahavi 2014: 141-6; Taipale 2016; Léon \& Zahavi 2016).

In a similar vein, Gurwitsch maintains that others always and already are given in specific and at the same time typical, or more or less familiar horizons of sense, and as "as bearers of roles", and in more or less specific social "situations" (Gurwitsch 1977: 159 [111]). ${ }^{8}$

[others] do not surface "suddenly," "accidentally," or "by chance." [...] They immediately appear, instead, as existing concretely in the "co-included" situation. Not just any "human thing" emerges unexpectedly and sporadically [...]; it is rather the case that situations become visible in the horizons in which sellers, anonymous buyers, purveyers, employers, listeners, readers, masters, servants, etc., act out their roles. (Gurwitsch 1977: 139 [97]; cf. 153-9 [107-11])

Moreover, Gurwitsch maintains, even basic facial expressions and gestures, such as shaking the head and wrinkling the brow "are not in themselves unambiguous", but rather the comprehension of such "expressive phenomena smoothly arises from knowledge about the situation in which I am with others, and fits into this knowledge as one of its moments" (Gurwitsch 1977: 162 [113]). Here, Gurwitsch explicitly departs from Scheler's idea of "a universal grammar" regulating the "elementary" relations between experience and its expression (Scheler 1926a: 22; cf. Husserl 1912-1917: 166 [174-175]).

(2) Next, there is another important form of empathy, where empathiser and target are, in multiple ways, directly interacting in empathising, and may even engage in some form of collective intentionality or joint agency.

First, consider what we might call mutual empathy and what, for example, Stein, following Lipps, labels iterative empathy or reflexive sympathy (1917: 30, 106-7

${ }^{8}$ Gurwitsch was certainly influenced here by Schütz, but also explicitly draws on Löwith's (1928) congenial account of social "roles" in empathy. 
$[18,88-9]) .{ }^{9}$ Here, the content of a subject $S_{1}$ 's empathic act $E_{1}$ encompasses another subject $S_{2}$ 's empathic act, $E_{2}$, where $E_{2}$ might be directed at third-party subjects (viz. iterative) or at $\mathrm{S}_{1}$ herself (viz. reflexive empathy). This may happen without necessarily presupposing that $S_{2}$ has an empathic understanding of, or in any way takes into account, $\mathrm{S}_{1}$ 's empathising. On the hand, in such situations there will typically be such a relation of mutual understanding, or a common knowledge that both subjects are fully aware of their mutually empathizing with one another (and their empathic stances). This understanding may or may not be verbally or otherwise made explicit.

A related but distinct case is what we might call interactive empathy, or what Gurwitsch has notably explored in terms of "being together in a common situation" (Zusammensein in einer gemeinsamen Situation) and, in particular, in a situation of "partnership" or coordinated action, or generally, a so-called "consociate being together" (gebundene Zusammensein). ${ }^{10}$ According to Gurwitsch, by simply being assigned and grasping the role you play, or being an active participant in a situation, and perhaps even coordinating your actions with others, or cooperating in achieving a joint goal, you thereby gain an intimate understanding of others' roles. This in its turn permits a richer understanding of the others' desires, motivations, and intentions, since it familiarises you with the context of "relevance," as Schütz would put it (1932; Schutz \& Luckmann 1974), which is specific to the situation and which guides the intentions and motives of the agents. You thus gain, as it were, a 'view from within', i.e., from within a situation of being together.

While one confers with his partner, he faces the wishes, aims, and interests of the partner which, even when not explicitly expressed, are provided by the setting of the things. In virtue of the partner's comportment during the negotiations, his aims, motivations, etc., can be discovered. One orients his comportment with respect to the position disclosed by his partner [...] As a result, one's own comportment in the situation (Situationsverbalten) is tuned in on the other and takes account of him. (Gurwitsch 1977: 150 [105])

\footnotetext{
9 See also Husserl's distinction between "reciprocal" and "unilateral" or "one-sided" empathy (wechselseitige und einseitige Einfüblung; Husserl 1921-1928: 133, 135, cf. also 198-9, and Husserl 1905-1920: 98), and Schütz, who has also elaborated in detail on reciprocal face-to-face empathy, which he calls a "we-relation" (Wir-Beriehung), and which is distinguished from those forms of "Thou-attitudes" (Du-Einstellung) that have the "Thou-orientation" (DuOrientierung) of unidirectional empathy; see Schütz 1932: 227-252, and Schutz \& Luckmann 1974: 101-116.

${ }^{10}$ Notice that by the term 'interactive' empathy, here, we are not aiming at the more general theory of empathy that has recently been endorsed by some under the label of 'interaction theory' (Gallagher 2008; Fuchs \& de Jaegher 2009; cf., critically, Overgaard \& Michael 2013; Michael et al. 2014). For this reason, 'mutual empathy' might be the better term for present purposes. However, we wish to distinguish the two types mutual and interactive, hence our non-standard terminology.
} 
The point here is not only that 'interactive empathy' will facilitate the coordination of joint agency or collective intentionality of the two-though this may well happen-but, also, and conversely, that the very fact of being together in a shared situation with assigned roles to each, or even in a situation of shared goals and coordinated action, will provide clues for mutually empathising that might otherwise not be readily available or not be available at all (e.g., if there is no possibility of verbal communication, or otherwise easily available behavioural or bodily expressions). ${ }^{11}$

(3) Lastly-and probably most contentiously-there is the possibility of shared or collective empathy. ${ }^{12}$ Think here of two types of cases. (i) First, consider cases in which the object of empathy is either a pair of individuals' or even a directly perceived or present group of individuals' shared experiential, emotional, or mental life (e.g., with a community of grievers); (ii) secondly, cases, in which the empathizing subjects constitute pairs, jointly engaging in the performance of empathic acts. In either of these cases, we may have various membership relations between these subjects, which tie together empathizers among themselves, or where empathizers or targets belong to the same or different groups.

An illustrative example of shared empathy is surely Scheler's famous scenario of two parents, A and B, grieving over the loss of their deceased child, where a friend $\mathrm{C}$ sees them standing at the child's bedside, empathizes with their shared feeling, and eventually commiserates upon their sorrow (Scheler 1926a: 23-4 [12-3]). Notice that this much-debated example (e.g., Schmid 2014; Zahavi 2015 and in this volume) is usually taken to illustrate the emotional sharing or integration of what Scheler (1926a) calls 'feeling-' or 'experiencing-together' (Miteinanderfüblen, Miteinander-erleben) in contrast to empathic understanding (Nachfüblen). However, this is indeed just one aspect of Scheler's example, and one shouldn't lose sight of the other, equally central aspect of the possibility of (collective) empathy with an instance of feeling-together, that we discuss here, and which is a point Scheler stresses too. ${ }^{13}$

${ }^{11}$ For a similar contemporary proposal, see Butterfill 2013; consider, however, that Butterfill's account of "interactive mindreaders" is-in contrast to the phenomenological onecouched in inferentialist terms.

12 Above and beyond systematic reasons, there is some, however scant, textual evidence that Stein, for one, indeed conceives of non-dyadic, or even collective, forms of empathy, in which the subject with whom one empathises is not another ego but a 'We' (1917: 29f. [178]; cf. 1922: 115 [136]). There is also a different but cogent type of other-directed act we find in Husserl called "social experience" (soziale Erfahrung), which "presents" "social objectivities" as such (Husserl 1912-1917: 200 [210]), or is an "intuitive realization of the sense of a social concept" (Husserl 1905-1920: 99). But see esp. Salice \& Taipale (2015) who forcefully argue for "group-directed empathy".

${ }^{13}$ For Scheler's complex theory of (shared) feelings, see Schloßberger 2016; for an early but still valuable account of Scheler's original critique of both Lipp's as well as the Husserl's and 
Notice that a necessary requirement for such shared empathy is that the empathizer recognizes the group members as reciprocally empathizing with one another. Obviously, this is not sufficient; after all individuals may mutually empathize with one another without necessarily sharing any experiences. The group members must be additionally conceived of as properly sharing some experience, rather than simply being taken as a random collection or contingent aggregation of intentionally unrelated individuals expressing the same emotion (e.g., a cheering fan-club, viewed as a crowd amassed via emotional contagion, where the individuals may not even be aware of their exhibiting the same affective behaviour, let alone of their 'sharing'). ${ }^{14}$ That is, we need to clearly distinguish shared emotions from simply being causally affected by others' emotions, i.e., without being aware of such influences, or from automatically mimicking those emotions, or from emotional contagion (Gefüblsansteckung; Stein 1917, and 1922; Scheler 1926a; cf. Goldie 2000: 176-205). Moreover, in order to empathically grasp that others share emotions, one need not have any emotional stance towards the object of the shared emotion, nor need one partake in the affective sharing of those others, let alone presuppose any fusion or 'emotional identification' (Einsfühlung; Scheler 1926a) of the empathiser with the respective group members. ${ }^{15}$ One might even empathically grasp shared emotions and feel excluded from the group, or disapprove or be antipathetic to the shared emotion while empathically grasping it. In such cases we would certainly be reluctant to say that an empathiser and her targets share any emotion. ${ }^{16}$

Now, a further moot question is whether or not collectives, corporations or other groups can be proper subjects (not only objects) of empathizing. In such a case the empathic act would not only be distributed across individual members, but would have rather a plural subject as its bearer. In any case, even if one denies

Stein's concepts of empathy, and an exposition of his own account of the perception of the other (Fremdwabrnebmung), see Schütz 1942.

${ }^{14} \mathrm{We}$ cannot go here into what further requirements collective or shared emotions must fulfill, see for more Szanto 2015; Szanto \& Zahavi (forthcoming) and Zahavi 2015.

${ }_{15}$ Phenomenologists indeed typically maintain the converse, i.e., hold that face-to-face empathic encounter is a necessary (though not sufficient) requirement not only for more complex or more mediated social relations (e.g., Schutz \& Luckmann 1974: 98-100), but also for collective intentionality and shared emotions, (e.g., Walther 1922: 73-9; Zahavi 2015).

16 There is a congenial but little-known set of conceptual distinctions in Walther (1922: 7080) concerning differences in emotional sharing. She distinguishes (i.) Einfüblen, understood in the phenomenologically standard way, (ii.) Mitfüblen ('emotional sharing') as reenacting the same type of experience or emotion as the target subject, but only for the sake of the other or on the other's behalf, and hence not fully 'appropriated' as one's own experience (e.g., I'm happy for you that your presentation went well) (cf. similarly, Stein 1917: 24-5 [15-16]); further (iii.) one might actively initiate a certain affective similarity between oneself and another, or affectively mimic the target (Nachabmen), however without any empathetic concern for the other as in (ii.), but merely to gain a first-personal understanding of the experience of another, and finally (iv.) Miteinandererleben as experiential sharing properly speaking. 
the possibility of such non-summative forms of empathy, one may still opt for genuinely collective forms of empathy in cases when two or more individuals cooperatively or jointly empathise with a third-party and coordinate their respective empathic acts accordingly.

Consider, as a kind of inverse case to Scheler's example, two empathisers $\mathrm{A}$ and $\mathrm{B}$ jointly attending to a third person C's expression of fear and distress. In doing so, $A$ and $B$ will not only share the focus of the empathic attention towards $\mathrm{C}$, but may also reflexively empathize with one another, and signal this to each other and/or to $\mathrm{C}$. When $\mathrm{C}$ bursts into tears, $\mathrm{A}$ and $\mathrm{B}$, witnessing this together, may exchange worried glances to each other, and may even signal to one another a desire not to let this be seen by $\mathrm{C}$ so as not increase her distress even more. This may eventually result in a shared empathic experience, such that $\mathrm{A}$ and $\mathrm{B}$ can be said to constitute, as it were, an 'empathiser of their own'. Consider that even in this case, it is not any concern shared by the empathisers that makes their act of empathy an act of empathy, nor is this what it makes it an act of collective empathy; rather, it is their shared focus or target what makes it thus. Once being such a shared instance, $\mathrm{A}$ and $\mathrm{B}$ might then indeed share some emotions (maybe even with $\mathrm{C}$ ), but this would not itself constitute their shared empathic access to the other.

\section{Concluding Remarks}

In contrast to the sceptical approach mentioned in the introduction, the aim of this article was to show that the phenomenological tradition harbours arguably one of the most elaborate conceptual frameworks for thematising empathy, both distinguishing it from related but different phenomena of social interaction (sympathy, emotional contagion, shared emotions, etc.), and offering a rich and radical account of its unitary yet multi-layered character. Moreover, while we have largely focused on presenting the core arguments of the classic phenomenologists, we nevertheless hope to have indicated various way in which their ideas overlap and may indeed contribute to contemporary discussions in both social cognition and collective intentionality research, not least of all by conceptualizing forms of empathy that are not yet sufficiently acknowledged in these debates. 


\section{Bibliography}

Butterfill, S. (2013) “Interacting Mindreaders," Philosophical Studies 165(3), 841-63.

Chelstrom, E. (2013) Social phenomenology: Husserl, intersubjectivity, and collective intentionality, Lanham et al.: Lexington.

Coplan, A. (2011) "Will the real empathy please stand up? A case for a narrow conceptualization," The Southern Journal of Philosophy 49(s1), 40-65.

Currie, G. (2008) “Some ways to understand people," Philosophical Explorations 11(3), 21118.

De Vignemont, F. \& Jacob, P. (2012) "What is it like to feel another's pain?," Philosophy of Science 79(2), 295-316.

Dullstein, M. (2013) "Direct perception and simulation: Stein's account of empathy," Review of Philosopby and Psychology 4(2), 333-50.

Fuchs, T. \& De Jaegher, H. (2009) "Enactive intersubjectivity: participatory sensemaking and mutual incorporation," Phenomenology and the Cognitive Sciences 8(4), 46586.

Gallagher, S. (2008) "Inference or interaction: Social cognition without precursors," Philosophical Explorations 11(3), 163-74.

- (2012) "In defense of phenomenological approaches to social cognition: interacting with the critics," Review of Philosophy and Psychology 3(2), 187-212.

Gallagher, S. \& Zahavi, D. (2012) The Phenomenological Mind. An Introduction to Philosophy of Mind and Phenomenology, London, New York: Routledge.

Goldie, P. (2000) The Emotions. A Philosophical Exploration, Oxford: Oxford University Press.

Gurwitsch, A. (1977 [1931]) Die mitmenschlichen Begegnungen in der Milieuwelt, ed. A. Metraux, Berlin, New York: de Gruyter. [Engl. (1979) Human Encounters in the Social World, transl. F. Kersten, Pittsburgh: Duquesne University Press.]

Hein, G. \& Singer, T. (2008), "I feel how you feel but not always: the empathic brain and its modulation," Current Opinion in Neurobiology 18(2), 153-158.

Herschbach, M. (2008) "Folk psychological and phenomenological accounts of social perception," Philosophical Explorations 11(3), 223-235.

Husserl, E. (1905-1920 [1973]): Zur Phänomenologie der Intersubjektivität. Texte aus dem Nachlaß. Erster Teil: 1905-1920, [=Husserliana XIII] ed. I. Kern, The Hague: Martinus Nijhoff.

_ (1907 [1973]) Ding und Raum: Vorlesungen 1907, [=Husserliana XVI] ed. U. Claesges, The Hague: Martinus Nijhoff. [Engl. (2010) Thing and Space: Lectures of 1907, transl. R. Rojcewicz, Dordrecht: Kluwer.]

—_ (1912-1916 [1952]): Ideen zu einer reinen Phänomenologie und phänomenologischen Philosophie. Zweites Buch: Phänomenologische Untersuchungen zur Konstitution, [=Husserliana IV] ed. M. Biemel, The Hague: Martinus Nijhoff. [Engl. (1989) Ideas pertaining to a pure phenomenology and to a phenomenological philosophy. Second book Studies in the phenomenology of constitution, transl. R. Rojcewicz \& A. Schuwer, Dordrecht: Kluwer.]

— (1915-1917 [2016]): Ideen ₹u einer reinen Pbänomenologie und pbänomenologischen Pbilosophie. Zweites Buch: Phänomenologische Untersuchungen zur Konstitution und Wissenschaftstheorie, [=Husserliana IV-2/V-2] ed. D. Fonfara, Dordrecht: Springer.

— (1918-1926 [1966]): Analysen zur passiven Synthesis. Aus Vorlesungs- und Forschungsmanuskripten 1918-1926, [=Husserliana XI] ed. M. Fleischer, The Hague: Martinus 
Nijhoff. [Engl. (2001) Analyses concerning passive and active synthesis. Lectures on Transcendental Logic, transl. A. Steinbock. Dordrecht: Kluwer.]

(1921-1928 [1973]): Zur Phänomenologie der Intersubjektivität. Texte aus dem Nacblaß. Zweiter Teil: 1921-1928, [=Husserliana XIV] ed. I. Kern, The Hague: Martinus Nijhoff.

_ (1931 [1973]): Cartesianische Meditationen und Pariser Vorträge, [=Husserliana I] ed. S. Strasser, The Hague: Martinus Nijhoff. [Engl. (1960) Cartesian Meditations. An Introduction to Phenomenology, transl. D. Cairns. The Hague: Martinus Nijhoff.]

Jardine, J. (2014) "Husserl and Stein on the Phenomenology of Empathy: Perception and Explication," Synthesis Philosophica 58(2), 273-88.

(2015) "Stein and Honneth on Empathy and Emotional Recognition," Human Studies 38(4), doi: 10.1007/s10746-015-9361-5.

Jacob, P. (2011) “The direct-perception model of empathy: a critique," Review of Philosophy and Psychology 2(3), 519-40.

Jensen, R. T. \& Moran, D. (2012) "Introduction: Intersubjectivity and empathy," Phenomenology and the Cognitive Sciences 11(2), 125-33.

Krueger, J. (2012) "Seeing mind in action," Phenomenology and the Cognitive Sciences 11(2), $149-73$.

León, F. \& Zahavi, D. (2016) "Phenomenology of experiential sharing: The contribution of Schutz and Walther," in A. Salice \& H. B. Schmid (eds.) Social Reality: The Phenomenological Approach, Dordrecht: Springer.

León, F. (2016) "An Interactionist Approach to Shared Cognition: Some Prospects and Challenges," in T. Szanto \& D. Moran (eds.) The Phenomenology of Sociality. Discovering the ' $W e$ ', London, New York: Routledge.

Lipps, T. (1907) "Das Wissen von fremden Ichen," in T. Lipps (ed.) Psychologische Untersuchungen I, Leipzig: Engelmann.

_ (1909) Leiffaden der Psychologie, Leipzig: Verlag von Wilhelm Engelmann.

Löwith, K. (1928) Das Individuum in der Rolle des Mitmenschen, Freiburg i.B./München: Alber.

Ludwig, K. \& Jankovic, Marija (Eds.) (2016) The Routledge Handbook of Collective Intentionality, London, New York: Routledge.

Overgaard, S. (2007) Wittgenstein and Other Minds: Retbinking Subjectivity and Intersubjectivity with Wittgenstein, Levinas, and Husserl, London, New York: Routledge.

Overgaard, S. (2012) "Other People," in D. Zahavi (ed.) The Oxford Handbook of Contemporary Phenomenology, Oxford: Oxford University Press.

Overgaard, S. \& Michael, J. (2015) “The Interactive Turn in Social Cognition Research: A Critique," Philosophical Psychology 28(2), 160-83.

Mallgrave, H. \& Ikonomou, E. (1994) "Introduction," in H. F. Mallgrave (ed.) Empathy, Form, and Space: Problems in German Aesthetics 1873-1893, Santa Monica: The Getty Center for the History of Art and the Humanities.

Merleau-Ponty, M. (1945) Phénoménologie de la perception, Paris: Gallimard. [Engl. (2012) Phenomenology of Perception, transl. C. Smith, London, New York: Routledge.]

Michael, J., Christensen, W. \& Overgaard, S. (2014) "Mindreading as social expertise," Synthese 191(5), 817-40.

Salice, A. \& Taipale, J. (2015) "Group-Directed Empathy: A Phenomenological Account," Journal of Phenomenological Psychology 46(2), 163-84. 
Scheler, M. (1926a [1980]). Der Formalismus in der Ethik und die material Wertetbik. Neuer Versuch der Grundlegung eines ethischen Personalismus, Bern: Francke. [Engl. (1973) Formalism in Ethics and Non-Formal Ethics of V alues: A New Attempt Toward the Foundation of an Ethical Personalism, transl. M. S. Frings \& R. L. Funk, Evanston: Northwestern University Press.]

(1926b [2005]) Wesen und Formen der Sympathie, Bonn: Bouvier 2005. [Engl. (1954) The Nature of Sympathy, transl. P. Heath. London: Routledge \& Kegan Paul.]

Schloßberger, M. (2016) "The Varieties of Togetherness: Scheler on Collective Affective Intentionality," in A. Salice \& H. B. Schmid (eds.) Social Reality: The Phenomenological Approach, Dordrecht: Springer.

Schütz, A. (1932 [1974]) Der sinnhafte Aufbau der sozialen Welt. Eine Einleitung in die verstehende Soziologie, Frankfurt a.M.: Suhrkamp. [Engl. (1967) The Phenomenology of the Social World, transl. G. Walsh \& F. Lehnert, Evanston: Northwestern University Press.]

_ (1942) "Scheler's Theory of Intersubjectivity and the General Thesis of the Alter Ego," Philosophy and Phenomenological Research (2)3, 323-47.

Schutz, A. \& Luckmann, T. (1974) The Structures of the Life-world, transl. R. M. Zaner \& H. Tristram Engelhardt, London: Heinemann.

Shum, M. (2012) "Edith Stein and the Problem of Empathy: Locating Ascription and a Structural Relation to Picture Consciousness," Journal of the British Society for Phenomenology 43(2), 178-94.

Smith, J. (2010) "Seeing other people," Philosophy and Phenomenological Research 81(3), 731 48.

Spaulding, S. (2010) "Embodied cognition and mindreading," Mind and Language 25(1), $119-40$.

— (2015) "Phenomenology of Social Cognition," Erkenntnis 80(5), 1069-89.

Stein, E. (1917 [2008]) Zum Problem der Einfïblung, Freiburg: Herder. [Engl. (1989) On the Problem of Empathy, transl. W. Stein, Washington, D.C.: ICS Publication.]

—_ (1920 [2010]) Beiträge zur philosophischen Begründung der Psychologie und der Geisteswissenschaften, Freiburg: Herder. [Engl. (2000) Philosophy of Psychology and the Humanities, transl. M. C. Baseheart \& M. Sawicki, Washington, D.C.: ICS Publication.]

Szanto, T. (2015) "Collective Emotions, Normativity, and Empathy: A Steinian Proposal," Human Studies 38(4), doi: 10.1007/s10746-015-9350-8.

_ (2016) "Husserl on Collective Intentionality," in A. Salice \& H. B. Schmid (eds.) Social Reality: The Phenomenological Approach, Dordrecht: Springer.

Szanto, T. \& Moran, D. (2016) "Introduction: Phenomenological Discoveries Concerning the 'We': Mapping the Terrain," in T. Szanto \& D. Moran (eds.) The Phenomenology of Sociality. Discovering the 'We', London, New York: Routledge.

- (Eds.) (2015) Empathy and Collective Intentionality. The Social Philosophy of Edith Stein, Special Issue: Human Studies 38(4).

_ (Eds.) (2016) The Phenomenology of Sociality. Discovering the 'We', London, New York: Routledge.

Taipale, J. (2016) "From Types to Tokens: Empathy and Typification," in T. Szanto \& D. Moran (eds.) The Phenomenology of Sociality. Discovering the 'We'. London, New York: Routledge. 
Theunissen, M. (1965 [1984]) The Other: Studies in the Social Ontology of Husserl, Heidegger, Sartre, and Buber. Cambridge, MA/London: MIT Press, 1984.

Titchner, E. B. (1909) Lectures on the Experimental Psychology of Thought-Processes, New York: Macmillan.

Vischer, R. (1873) Über das optische Formgefübl: Ein Beitrag zur Ästhetik. Leipzig: Hermann Credner.

von Scheve, C. \& Salmela, M (Eds.) (2014) Collective Emotions, Oxford: Oxford University Press.

Walther, G. (1922) “Zur Ontologie der sozialen Gemeinsachten," in Jabrbuch für Philosophie und pbänomenologische Forschung 6, 1-158.

Zahavi, D. (2001) "Beyond empathy. Phenomenological approaches to intersubjectivity," Journal of Consciousness Studies 8(5-7), 151-67.

- (2011) "Empathy and direct social perception: a phenomenological proposal," Review of Philosophy and Psychology 2(3), 541-58.

- (2014) Self and Other: Exploring Subjectivity, Empathy, and Shame, Oxford: Oxford University Press.

— (2015) "You, Me, and We: The Sharing of Emotional Experiences," Journal of Consciousness Studies 22(1-2), 84-101. 